\title{
PENTINGNYA MEMAHAMI KARAKTERISTIK SISWA SEKOLAH DASAR DI SDN CIKOKOL 2
}

\author{
Nevi Septianti \& Rara Afiani \\ Universitas Muhammadiyah Tangerang \\ neviseptianti@gmail.com, rara.afiani11@gmail.com
}

\begin{abstract}
This study is based on the existence of learning activities that are less responsive to various individual characteristics. To meet these demands, teachers need to understand students' characteristic. If the teacher in delivering the lesson material less attention to the characteristics of the students and the personality traits of students is not used as a foothold in learning, students will have difficulty understanding the subject matter. Whatever efforts are chosen and performed by the teacher and the lesson designer if they are not based on individual characteristics of the student as subject of learning, then the developed learning will not be meaningful for the students. Characteristics of students is very important to know by educators, because it is very important to be a reference in formulating learning strategies. Learning strategy is developed by teachers and implemented through learning methods to the students so that the learning objectives can be achieved effectively and efficiently. This research uses qualitative descriptive approach and data collection techniques used are interview, observation, and documentation in SDN Cikokol 2.
\end{abstract}

Keywords: Characteristics of Students, Learning, Learning Strategies

\begin{abstract}
Abstrak : Penelitian ini dilatar belakangi dari adanya kegiatan pembelajaran yang kurang tanggap terhadap berbagai macam karakteristik individu. Untuk memenuhi tuntutan tersebut, guru perlu memahami karaketeristik siswanya. Jika guru dalam menyampaikan materi pelajaran kurang memperhatikan karakteristik siswa dan ciriciri kepribadian siswa tidak dijadikan pijakan dalam pembelajaran, siswa akan mengalami kesulitan memahami materi pelajaran. Upaya apa pun yang dipilih dan dilakukan oleh guru dan perancang pembelajaran jika tidak bertumpu pada karakteristik perseorangan siswa sebagai subjek belajar, maka pembelajaran yang dikembangkan tidak akan bermakna bagi siswa. Karakteristik siswa sangat penting untuk diketahui oleh pendidik, karena ini sangat penting untuk dijadikan acuan dalam merumuskan strategi pembelajaran. Strategi pembelajaran disusun oleh guru dan diimplementasikan melalui metode pembelajaran kepada siswa agar tujuan pembelajaran dapat dicapai secara efektif dan efisien. Penelitian ini menggunakan pendekatan deskriptif kualitatif dan teknik pengumpulan data yang digunakan yaitu wawancara, observasi, dan dokumentasi di SDN Cikokol 2.
\end{abstract}

Kata Kunci: Karakteristik Siswa, Pembelajaran, Strategi Pembelajaran

As-Sabiqun : Jurnal Pendidikan Islam Anak Usia Dini

Volume 2, Nomor 1, Maret 2020; 7-17

https://ejournal.stitpn.ac.id/index.php/assabiqun 


\section{PENDAHULUAN}

Pendidikan merupakan sarana strategis untuk meningkatkan kualitas bangsa karenanya kemajuan bangsa dan kemajuan pendidikan merupakan suatu determinasi. Dalam keseluruhan proses pendidikan di sekolah, pembelajaran menjadi ujung tombak bagi terciptanya pendidikan yang berkualitas. Hanya dengan pembelajaran yang berkualitaslah suatu instansi dapat menghasilkan lulusan yang berkualitas. Dalam tataran operasional, tenaga pendidik memiliki tugas dan tanggung jawab bagi terselenggaranya pembelajaran yang berkualitas. Untuk itu sangat penting bagi tenaga pendidik memiliki kompetensi dan standar kualifikasi pendidikan agar pembelajaran mencapai efektivitas dan efisiensinya

Perkembangan zaman telah membuat perkembangan dalam pendidikan terkait ilmu pengetahuan dan teknologi serta menciptakan persaingan global secara ketat. Agar mampu berperan dalam persaingan global, maka sebagai bangsa kita perlu terus mengembangkan dan meningkatkan kualitas sumber daya manusianya. Oleh karena itu, peningkatan kualitas sumber daya manusia merupakan kenyataan yang harus dilakukan secara terencana, terarah, intensif, efektif dan efisien dalam proses pembangunan, kalau tidak ingin bangsa ini kalah bersaing dalam menjalani era globalisasi tersebut. Pendidikan di era global diharapkan mampu mengatasi permasalahan pendidikan terkait moral dan sosial masyarakat Indonesia, khususnya peserta didik. Pendidikan ini melahirkan konsep baru yaitu pendidikan abad 21 dimana pembelajaran ini memiliki perbedaan dengan pembelajaran di masa yang lalu. Untuk mengembangkan pembelajaran abad 21, guru harus memulai satu langkah perubahan yaitu merubah pola pembelajaran tradisional yang berpusat pada guru menjadi pola pembelajaran yang berpusat pada peserta didik (student center).

Banyak faktor penyebab kualitas pendidikan rendah, di antaranya kegiatan pembelajaran yang kurang tanggap terhadap kemajemukan individu dan lingkungan tempat siswa berada. Pembelajaran demikian kurang bermanfaat bagi siswa. Agar pembelajaran bermakna, perlu dirancang dan dikembangkan berdasarkan pada kondisi siswa sebagai subjek belajar dan komunitas budaya tempat siswa tinggal. Siswa adalah manusia yang memiliki sejarah, makhluk dengan ciri keunikannya (individuallitas). Pemahaman akan subjek belajar harus dimiliki oleh guru atau tenaga 
kependidikan lainnya untuk dijadikan pijakan dalam mengembangkan teori ataupun praksis-praksis pendidikan dan pembelajaran.

Menurut Vygotsky agar pembelajaran bermakna, perlu dirancang dan dikembangkan berpijak pada kondisi siswa sebagai subjek belajar serta komunitas sosial-kultural tempat siswa tinggal (Moll, 1994). Menurut Waidl (Admadi \& Setiyaningsih, 2004), hal penting yang harus dipahami yang berkaitan dengan siswa atau peserta belajar sebagai individu bahwa siswa adalah manusia yang memiliki sejarah, makhluk dengan ciri keunikan (individualitas), selalu membutuhkan sosialisasi di antara mereka, memiliki hasrat untuk melakukan hubungan dengan alam sekitar, dan dengan kebebasannya mengolah pikir dan rasa akan pertemuannya dengan yang transendental. Pemahaman terhadap siswa sebagai subjek belajar inilah yang harus dijadikan pijakan dalam mengembangkan teori-teori maupun praksis-praksis pendidikan.

Karakteristik peserta didik sangat penting untuk diketahui oleh pendidik, karena ini sangat penting untuk dijadikan acuan dalam merumuskan strategi pengajaran. Strategi pengajaran terdiri atas metode dan teknik atau prosedur yang menjamin siswa mencapai tujuan.. Strategi dan metode pembelajaran berguna untuk mencapai tujuan pembelajaran yang diinginkan. Menurut Kemp dalam Wina Senjaya (2008) mengemukakan bahwa strategi pembelajaran adalah suatu kegiatan pembelajaran yang harus dikerjakan guru dan siswa agar tujuan pembelajaran dapat dicapai secara efektif dan efisien. Selanjutnya, dengan mengutip pemikiran J.R.David , Wina Senjaya (2008) menyebutkan bahwa dalam strategi pembelajaran terkandung makna perencanaan. Artinya, bahwa strategi pada dasarnya masih bersifat konseptual tentang keputusan-keputusan yang akan diambil dalam suatu pelaksanaan pembelajaran. Dilihat dari strateginya, pembelajaran dapat dikelompokkan ke dalam dua bagian pula, yaitu: 1) exposition-discovery learning dan 2) group-individual learning (Rowntree dalam Wina Senjaya, 2008). Persoalan yang terjadi saat ini adalah masih banyak pendidik yang masih belum dapat membedakan antara strategi pembelajaran dengan metode pembelajaran. Bahkan masih ada juga pendidik yang salah memperlakukan peserta didik karena kurang pahamnya dalam melihat 
karakteristik yang dimiliki peserta didik, sebab karakteristik peserta didik setiap tingkatannya berbeda-beda.

Reigeluth (1983) sebagai seorang ilmuan pembelajaran, bahkan secara tegas menempatkan karakteristik siswa sebagai satu variabel yang paling berpengaruh dalam pengembangan strategi pengelolaan pembelajaran. Pakar pembelajaran seperti Banathy, Romiszowski, Dick dan Carey, Gagne dan Degeng, menempatkan langkah analisis karakteristik siswa pada posisi yang sangat penting sebelum langkah pemilihan dan pengembangan strategi pembelajaran. Semua ini menunjukkan bahwa model pembelajaran apapun yang dikembangkan atau strategi apapun yang dipilih untuk keperluan pembelajaran haruslah berpijak pada karakteristik perseorangan atau kelompok dari siapa yang belajar. Untuk mengembangkan strategi pembelajaran yang optimal, terlebih dahulu guru perlu mengetahui karakteristik siswa sebagai pijakannya.

Degeng (1991:6) mengatakan bahwa karakteristik siswa adalah aspekaspek atau kualitas perseorangan siswa yang telah dimilikinya. Menganalisis karakteristik siswa dimaksudkan untuk mengetahui ciri-ciri perseorangan siswa. Hasil dari kegiatan ini akan berupa daftar yang memuat pengelompokkan karakteristik siswa, sebagai pijakan untuk mempreskripsikan metode yang optimal guna mencapai hasil belajar tertentu. Langkah-langkah mendesain pembelajaran menurut Degeng (1991) adalah (1) melakukan analisis tujuan dan karakteristik materi pembelajaran. (2) menganalisis sumber-sumber belajar (kendala). (3) melakukan analisis karakteristik siswa. (4) menetapkan tujuan belajar dan isi pembelajaran. (5) menetapkan strategi pengorganisasian isi pembelajaran. (6) menetapkan strategi penyampaian isi pembelajaran. (7) menetapkan strategi pengelolaan pembelajaran. mengembangkan prosedur pengukuran hasil pembelajaran.

Analisis karakteristik siswa dilakukan setelah perancang pembelajaran mengidentifikasi tujuan pembelajaran yang ingin dicapai. Juga ditunjukkan bahwa hasil analisis karakteristik siswa selanjutnya dijadikan pijakan kerja dalam memilih, menetapkan, dan mengembangkan strategi pengelolaan pembelajaran. Dengan konteks seperti ini, menjadi semakin jelas perlunya dilakukan penelitian karakteristik siswa yang berkaitan dengan kefektifan pembelajaran agar dapat dipakai sebagai dasar 
bagi para ilmuwan dan teknolog pembelajaran serta para guru dalam mendesain program-program pembelajaran.

Jika dalam menyampaikan materi pelajaran guru kurang memperhatikan karakteristik siswa dan ciri-ciri kepribadian siswa tidak dijadikan pijakan dalam pembelajaran, siswa akan mengalamai kesulitan memahami materi pelajaran. Mereka merasa bosan, bahkan timbul kebencian terhadap materi pelajaran yang diajarkan oleh guru. Kondisi demikian sebagai penyebab rendahnya kualitas dan kuantitas proses serta hasil belajar yang telah diprogramkan. Upaya apa pun yang dipilih dan dilakukan oleh guru dan perancang pembelajaran jika tidak bertumpu pada karakteristik perseorangan siswa sebagai subjek belajar, maka pembelajaran yang dikembangkan tidak akan bermakna bagi siswa.

Karakteristik siswa yang dapat diidentifikasi sebagai faktor yang amat berpengaruh terhadap proses dan hasil belajar adalah kecerdasan, kemampuan awal, gaya kognitif, gaya belajar, motivasi, dan faktor sosial-budaya. Informasi tentang tingkat perkembangan kecerdasan siswa amat diperlukan sebagai pijakan dalam memilih komponen-komponen dalam pembelajaran, seperti tujuan pembelajaran, materi, media, strategi pembelajaran, dan evaluasi (Gardner, 1993; Amstrong, 1994).

Menurut Suparno (2001), siswa yang berada pada tahap pemikiran operasional konkret sudah memiliki kecakapan berpikir logis, tetapi hanya melalui benda-benda konkret sehingga semua komponen pembelajaran perlu disesuaikan dengan kemampuan tersebut. Sebaliknya, mereka yang sudah berada pada tahap operasi formal sudah mampu berpikir abstrak dan logis dengan menggunakan pola berpikir "kemungkinan". Mereka sudah dapat berpikir ilmiah, baik deduktif maupun induktif, serta mampu menarik kesimpulan, menafsirkan dan mengembangkan hipotesis. Oleh sebab itu, komponenkomponen pembelajaran sudah dapat dirancang sedemikian rupa untuk diarahkan pada kemampuan tersebut.

Dengan karakteristik siswa yang telah diuraikan seperti di atas, guru dituntut untuk dapat mengemas perencanaan dan pengalaman belajar yang akan diberikan kepada siswa dengan baik, menyampaikan hal-hal yang ada di lingkungan sekitar kehidupan siswa sehari-hari, sehingga materi pelajaran yang dipelajari tidak abstrak dan lebih bermakna bagi anak. 
Selain itu, siswa hendaknya diberi kesempatan untuk pro aktif dan mendapatkan pengalaman langsung baik secara individual maupun dalam kelompok.

Sementara itu, Paulina Pannen (dalam Padmo, 2003:221) menegaskan bahwa dalam merancang dan melaksanakan pembelajaran, jika dikaitkan dengan karakteristik budaya siswa, hasil belajar siswa akan meningkat. Ia mengatakan bahwa guru dalam melaksanakan tindak belajar harus berpijak pada budaya siswa karena latar belakang budaya siswa akan berpengaruh terhadap proses dan hasil belajarnya.

Berdasarkan uraian tentang pemahaman karakteristik siswa dalam pembelajaran di atas, serta melihat kondisi belum optimalnya hasil belajar siswa saat ini, tugas yang diemban para pendidik dan perancang di bidang pembelajaran sangat rumit karena harus berhadapan dengan sejumlah variabel kondisi yang berada di luar kontrolnya. Satu variabel yang sama sekali tidak dapat dimanipulasi oleh guru atau perancang pembelajaran adalah karakteristik siswa. Variabel ini mutlak harus dijadikan pijakan dalam memilih dan mengembangkan strategi pembelajaran yang optimal. Upaya apapun yang dipilih dan dilakukan oleh guru dan perancang pembelajaran harus bertumpu pada karakteristik perseorangan siswa sebagai subjek belajar.

\section{METODE PENELITIAN}

Pendekatan yang dilakukan dalam penelitian ini adalah pendekatan penelitian kualitatif yang bersifat deskriptif. Bogdan dan Biklen dalam Umar (2012) mengemukakan "bahwa keberhasilan penelitian deskriptif sangat ditentukan oleh ketelitian, kelengkapan catatan lapangan (field note) yang disusun peneliti dari hasil observasi, serta wawancara secara mendalam.”.

Adapun yang menjadi subjek dalam penelitian ini adalah Guru Kelas 3 dan 33 siswa SDN Cikokol 2. Pengumpulan data dalam penelitian kualitatif menggunakan beberapa teknik, yaitu: melalui observasi, wawancara dan dokumentasi. Ketiga metode pengumpulan data tersebut diharapkan dapat saling melengkapi sehingga diperoleh suatu informasi yang diharapkan.

Teknik analisis data penelitian kualitatif yaitu selama pengumpulan data penelitian merekam dan membuat catatan lapangan, melakukan memberchek dengan 
subjek penelitian yang bersangkutan, mengadakan audit trail (uji kecocokan data), melakukan triagulasi untuk mendapatkan keabsahan data. Analisis data dilakukan secara induktif dan secara terus menerus dan berproses. Sementara observasi dilakukan untuk mengamati proses pembelajaran yang dilaksanakan oleh guru kelas. Dokumen digunakan untuk memperoleh data Rencana Pelaksaan Pembelajaran (RPP) dan foto di SDN Cikokol 2.

Instrumen yang digunakan dalam penelitian ini adalah lembar wawancara dan lembar observasi. Lembar wawancara digunakan sebagai pedoman saat melakukan wawancara dengan guru kelas enam. Lembar observasi digunakan untuk mencatat hasil pengamatan selama observasi dalam proses pembelajaran di kelas, khususnya kelas enam. Peneliti melakukan analisis data mulai mengumpulkan data, menyajikan, mereduksi, dan menarik kesimpulan.

\section{HASIL PENELITIAN DAN PEMBAHASAN}

Berdasarkan hasil penelitian yang telah dilakukan di kelas 3 SDN Cikokol 2 terkait dengan pentingnya memahami karakteristik siswa sebagai dasar pengembangan strategi pengajaran. Peranan strategi pengajaran lebih penting apabila guru mengajar siswa yang berbeda dari segi kemampuan, pencapaian, kecenderungan, dan minat. Hal tersebut dikarenakan, guru harus memikirkan strategi yang mampu. Di sini, guru bukan saja harus meguasai berbagai kaidah mengajar, melainkan juga mengintegrasikan dan menyusun kaidahkaidah untuk membentuk strategi pengajaran yang paling berkesan dalam pengajarannya. Karakteristik siswa di kelas enam ternyata sangat beragam, hal ini diketahui saat wawancara dengan guru kelas enam sebelum memulai kegiatan observasi di dalam kelas. Dari hasil observasi melalui wawancara dan pengamatan dapat diketahui bahwa karakteristik utama siswa sekolah dasar yaitu memiliki perbedaan-perbedaan individual dalam banyak segi dan bidang, di antaranya, perbedaan dalam intelegensi, kemampuan dalam kognitif dan bahasa, perkembangan kepribadian dan perkembangan fisik anak. Anak kelas enam, memilki kemampuan tenggang rasa dan kerja sama yang lebih tinggi, bahkan ada di antara mereka yang menampakan tingkah laku mendekati tingkah laku anak remaja permulaan. 
Piaget mengidentifikasikan tahapan perkembangan intelektual yang dilalui anak yaitu : (a) tahap sensorik motor usia 0-2 tahun. (b) tahap operasional usia 2-6 tahun. (c) tahap opersional kongkrit usia 7-11 atau 12 tahun. (d) tahap operasional formal usia 11 atau 12 tahun ke atas.

Berdasarkan uraian di atas, siswa sekolah dasar berada pada tahap operasional kongkrit, pada tahap ini anak mengembangkan pemikiran logis, masih sangat terikat pada fakta-fakta perseptual, artinya anak mampu berfikir logis, tetapi masih terbatas pada objek-objek kongkrit, dan mampu melakukan konservasi.

Bertitik tolak pada perkembangan intelektual dan psikososial siswa sekolah dasar, hal ini menunjukkan bahwa mereka mempunyai karakteristik sendiri, di mana dalam proses berfikirnya, mereka belum dapat dipisahkan dari dunia kongkrit atau hal-hal yang faktual, sedangkan perkembangan psikososial anak usia sekolah dasar masih berpijak pada prinsip yang sama di mana mereka tidak dapat dipisahkan dari hal-hal yang dapat diamati, karena mereka sudah diharapkan pada dunia pengetahuan.

Pada usia ini mereka masuk sekolah umum, proses belajar mereka tidak hanya terjadi di lingkungan sekolah, karena mereka sudah diperkenalkan dalam kehidupan yang nyata di dalam lingkungan masyarakat. Nasution (1992) mengatakan bahwa masa kelas tinggi sekolah dasar mempunyai beberapa sifat khas sebagai berikut : (1) adanya minat terhadap kehidupan praktis sehari-hari yang kongkrit. (2) amat realistik, ingin tahu dan ingin belajar. (3) menjelang akhir masa ini telah ada minat terhadap hal-hal dan mata pelajaran khusus, oleh ahli yang mengikuti teori faktor ditaksirkan sebagai mulai menonjolnya faktor-faktor. (4) pada umumnya anak menghadap tugastugasnya dengan bebas dan berusaha menyelesaikan sendiri. (5) pada masa ini anak memandang nilai (angka rapor) sebagai ukuran yang tepat mengenai prestasi sekolah. (6) anak pada masa ini gemar membentuk kelompok sebaya, biasanya untuk bermain bersamasama.

Dengan karakteristik siswa yang telah diuraikan seperti di atas, guru dalam pembelajaran sudah terlihat mengemas perencanaan dan pengalaman belajar yang akan diberikan kepada siswa dengan baik, menyampaikan hal-hal yang ada di lingkungan sekitar kehidupan siswa seharihari, sehingga materi pelajaran yang dipelajari tidak abstrak dan lebih bermakna bagi anak. Selain itu, siswa juga diberi 
kesempatan untuk pro aktif dan mendapatkan pengalaman langsung baik secara individual maupun dalam kelompok. Hal ini berarti guru telah menjadikan karakter siswa sebagai pijakan dalam penentuan strategi pembelajaran dan metode pembelajaran.

Dewanti (2009: 25) membuktikan bahwa strategi pembelajaran yang digunakan guru jika disesuaikan dengan kebutuhan siswa akan meningkatkan efektivitas belajar siswa. Ia menyarankan, strategi pembelajaran di kelas seharusnya mempertimbangkan keadaan siswa dan manfaatnya bagi kehidupan mereka seharihari. Penelitian Siskandar (2009:183) menambah bukti bahwa faktor internal atau faktor yang datang dari dalam diri siswa sangat berpengaruh terhadap hasil belajarnya. Untuk itu, ia menyarankan agar pembelajaran berpusat pada gaya belajar siswa atau pada bagaimana cara siswa menggunakan pengetahuannya.

Dengan demikian, bahan ajar modul sebaiknya dibuat sendiri oleh guru agar lebih menarik serta lebih konstektual dengan situasi dan kondisi sekolah maupun lingkungan sosial budaya peserta didik. Namun, saat ini masih jarang guru yang membuat bahan ajar sendiri, sebagian besar guru masih menggunakan bahan ajar yang beredar di pasaran (Ali Mustadi, 2015).

Karakteristik siswa adalah bagianbagian pengalaman siswa yang berpengaruh pada keefektifan proses belajar (Seels dan Richey, 1994). Penelitian tentang karakteristik siswa bertujuan untuk mendeskripsikan bagian kepribadian siswa yang perlu diperhatikan untuk kepentingan rancangan pembelajaran. Ardhana (1999) lebih jelas mengatakan bahwa karakteristik siswa adalah salah satu variabel dalam domain desain pembelajaran yang biasanya didefinisikan sebagai latar belakang pengalaman yang dimiliki oleh siswa termasuk aspek-aspek lain yang ada pada diri mereka seperti kemampuan umum, ekspektasi terhadap pembelajaran, dan ciriciri jasmani serta emosional siswa, yang memberikan dampak terhadap keefektifan belajar. Hal ini dibuktikan oleh hasil temuan Djohan (2009) yang menunjukkan bahwa kecerdasan sosial siswa di daerah (Tangerang) memiliki rerata lebih tinggi dibandingkan dengan rerata kecerdasan sosial siswa di kota besar (Jakarta). Artinya, guru di dalam memilih strategi pembelajaran harus mempertimbangkan kecerdasan atau kemampuan siswa yang relevan dengan strategi pembelajaran yang digunakan. Secara keseluruhan dari 
observasi mengenai pentingnya memahami karakteristik siswa sebagai dasar strategi pengajaran oleh guru sudah dimplementasikan dengan baik selama proses pembelajaran di SDN Cikokol 2.

\section{KESIMPULAN}

Guna meningkatkan kualitas pembelajaran, guru perlu menjadikan karakteristik siswa dan budayanya sebagai pijakan dalam mengembangkan prinsip- prinsip dan programprogram pembelajaran. Sebab, upaya apapun yang dipilih dan dilakukan oleh guru dan perancang pembelajaran jika tidak bertumpu pada karakteristik perseorangan siswa sebagai subjek belajar, pembelajaran yang dikembangkannya tidak akan bermakna bagi siswa.

Penelitian ini berpijak pada asumsi bahwa : (1) perbaikan kualitas pembelajaran diawali dari strategi pembelajaran. Perencanaan pembelajaran dapat dijadikan titik awal upaya perbaikan kualitas pembelajaran. Ini berarti bahwa perbaikan kualitas pembelajaran haruslah diawali dari perbaikan kualitas strategi pembelajaran; (2) desain pembelajaran diacukan kepada si belajar (siswa) secara perseorangan dan/atau kelompok. Siswa haruslah dijadikan titik acuan dalam mendesain pembelajaran. Tindakan atau perilaku belajar memang dapat dipengaruhi, tetapi tindakan atau perilaku belajar akan tetap berjalan sesuai dengan karakteristik siswa

\section{DAFTAR PUSTAKA}

Basri, Hasan. 2013. Landasan Pendidikan. Bandung: CV. PUSTAKA SETIA

Degeng.1991. Karakteristik Belajar Mahasiswa Berbagai Perguruan BTinggi di Indonesia. Jakarta: Depdikbud Dirjen Dikti Proyek Pengembangan Pusat Fasilitas Bersama Antar Universitas/IUC

Dewanti, S. 2009. "Keefektifan Perpaduan PCL dan Pelatihan Metakognitif dalam Meningkatkan Kemampuan Memecahkan Masalah Matematika". Jurnal Penelitian dan Evaluasi Pendidikan, Vol. 13, No. 1, hal. 21-37.

Djohan. 2009. "Kemampuan Musikalitas sebagai Sarana Pengembangan Keteramplan Sosial" Jurnal Penelitian dan Evaluasi Pendidikan, Vol. 13, No. 1, hal. 111-126 
Gardner, H. 1993. Multiple Intelligences: The Theory in Practice. New York:Basic Books.

Moll, L. C. (ed). 1994. Vygotsky and Education: Instructional Implications and Applications of Sociohistorycal Psychology. Cambrige: University Press.

Nasution.1992. Metod Research. Bandung: Jemmars.

Padmo, J D.2003.Faktor-faktor perancangan Pembelajaran MIPA Berbasis Budaya, (dalam Dewi Padmo, dkk.). Teknologi Pembelajaran. Jakarta: UT, Pustekom, IPTPI.

Reigeluth, C.M. 1983. Instructional Design: What is It and Why is It? Dalam C.M. Reigeluth (Ed.), Instructional Design Theories and Models: an Overview of Their Current Status. Hillsdale, N.J.: Lawrence Erlbaum Associates.

Sasmito, L. F., \& Mustadi, A. (2015). Pengembangan Lembar Kerja Siswa Tematik Integratif Berbasis Pendidikan Karakter Pada Siswa Sekolah Dasar.Jurnal Pendidikan Karakter, (1).

Seels, B. B. \& Richey, R. 1994. Instructional Technology: the Definition and Domains of The Field. Washington D. C.: AECT.

Siskandar. 2009. "Keefektifan Pendekatan Cooperative Learning dalam Meningkatkan Aktivitas dan Hasil Belajar Mahasiswa". Jurnal Ilmu Pendidikan, Vol.16, No. 3, hal. 178185.

Suparno, P. 2001. Teori Perkembangan Kognitif Jean Piaget. Yogyakarta: Penerbit Kanisius. 